\title{
ELABORATION AND CHARACTERIZATION OF NEW CERAMIC MATERIAL FROM CLAY AND PHOSPHOGYPSUM
}

\author{
Y. Rakhila ${ }^{1 *}$, A. Mestari ${ }^{1}$, S. Azmi ${ }^{1}$ and A. Elmchaouri ${ }^{1}$ \\ ${ }^{1}$ Laboratory of Physical Chemistry \& Bioorganic Chemistry, Faculty of Science and Techniques \\ Mohammedia, University Hassan II of Casablanca, Morocco. \\ *E-mail : younessrakhila@gmail.com
}

\begin{abstract}
Phosphogypsum (PG) generated from the phosphate beneficiation plant was investigated to be valued as raw material for ceramic materials (bricks). X-ray diffraction (XRD), X-ray fluorescence (XRF), Fourier Transformer Infra-Red spectroscopy (FTIR) and laser granulometer were used for the mineralogical, morphological, chemical and granulometric characterizations of raw materials. Firstly, the raw materials were ground, dried and mixed with various level phosphogypsum addition (from 0 to 50 percent by weight of clay). Secondly, the mixtures were spread out in a stainless steel mold while they were pressed using a hydraulic press to obtain compacted discs. Finally, the obtained materials were sintered in a programmable furnace. The study involved physical properties (density, porosity, and water absorption), chemical, thermal, structural and mechanical tests performed on ceramic materials. The obtained results showed that the ceramic with $40 \%$ of PG incorporation successfully satisfied the standard requirements. The increase in the percentage of PG contributing to decreasing the mechanical strength of the samples, but it is still higher than the standard limit. In addition, the thermal conductivity was decreased with the increase in the percentage of PG, which gives the prepared material the insulating property.
\end{abstract}

Keywords: Clay, Phosphogypsum, Ceramic, Mechanical, Physico-Chemical and Thermal studies.

(C) RASĀYAN. All rights reserved

\section{INTRODUCTION}

Phosphogypsum is a waste yielded from the phosphate beneficiation plant. It formed during the production of phosphoric acid by chemical attack of natural phosphates using sulfuric acid ${ }^{1}$. Phosphoric acid is the product of the attack of phosphate ore by sulfuric acid according to this reaction, where $\mathrm{X}$ is $\mathrm{OH}, \mathrm{F}, \mathrm{Cl}$ or $\mathrm{Fr}^{2}$.

$$
\mathrm{Ca}_{5}\left(\mathrm{PO}_{4}\right)_{3} \mathrm{X}+5 \mathrm{H}_{2} \mathrm{SO}_{4}+2 \mathrm{H}_{2} \mathrm{O} \longrightarrow 3 \mathrm{H}_{3} \mathrm{PO}_{4}+5 \mathrm{CaSO}_{4} .2 \mathrm{H}_{2} \mathrm{O}+\mathrm{HX}
$$

Approximately 4.5 tons of phosphogypsum is yielded in the manufacture of one ton of phosphoric acid using a wet process ${ }^{3}$. The average annual production of PG exceeds 100 million tons in the world ${ }^{4-7}$. The phosphogypsum consists of more than $90 \%$ of calcium sulphate hydrate (Gypsum), also contains approximately 5-6 wt.\% of impurities including heavy metals, fluoride and radionuclides ${ }^{8}$. The toxic substances are transported by wind over long distances and could contaminate soil and groundwater ${ }^{9-12}$. PG has the same properties as natural gypsum, including fast setting, fire resistance and thermal insulation but its water resistance and cracks resistance are generally low ${ }^{13}$. From a physical point, PG is a powder of low plasticity with a density between 2.27 and $2.40 \mathrm{~g} . \mathrm{cm}^{-3}$.

Several studies were carried out on the valorization of phosphogypsum. For example, the use of phosphogypsum as a retarder in Portland cement ${ }^{7}$, soil stabilization ${ }^{14}$, phosphogypsum plates ${ }^{15}$, anhydrite cement ${ }^{16}$, high-strength gypsum ${ }^{17}$, hollow blocks ${ }^{18}$, non-fired bricks ${ }^{19}$ etc. However, most of these studies, the incorporation of phosphogypsum is too low, which it cannot satisfy the objective of the valorization of this waste material.This study consists of reusing of PG in the manufacture of ceramics (bricks), with a large proportion and good thermal and chemical properties, which is a waste if it is stored without reuse it will be very dangerous for the environment and Morocco has large reserves of PG and clay.

Rasayan J. Chem., 11(4), 1552-1563(2018)

http://dx.doi.org/10.31788/RJC.2018.1144025

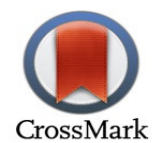


This study mainly investigated the effect of phosphogypsum addition with different replacing ratios of clay on the firing parameters and the properties of ceramic materials.

At first, the PG and the clay were characterized (granularity, chemical composition, FTIR and DRX). The second part deals with the elaboration of materials. Finally, the elaborated material was characterized using physical tests (density, water absorption and porosity), mechanical characteristics (compressive strength), chemical stability (resistance to attack by acids), thermal conductivity and the structure study.

\section{Raw Materials}

\section{EXPERIMENTAL}

The phosphogypsum used in this study is generated by the phosphate industry and has been recovered nearby khouribga regeion (Morocco). The used clay was collected from Ben-Ahmed district (location $33^{\circ} 06^{\prime} 43^{\prime \prime} \_\mathrm{N}$ and $\left.7^{\circ} 24^{\prime} 21^{\prime \prime} \_\mathrm{O}\right)$ of Morocco.

\section{Characterization Methods}

The chemical composition of the materials was determined by the XRF method, using an SRS 200 spectrometer. The mineralogical phases were identified by X-ray Diffraction (XRD) with Phillips Xpertpro diffractometer Bruker D8 advanced, Copper K $\alpha$ radiation $(\lambda=1.5406)$ working at $50 \mathrm{KV}$ and $20 \mathrm{~mA}$, Diffractograms were recorded from 5 to $85^{\circ}(2 \theta)$ with a step size of $0.02^{\circ}$ and a count time of 5 s per step. FTIR spectra were recorded on a Bruker Vertex-70 FT-IR spectrophotometer. The analyzed samples were mixed with anhydrous potassium bromide $(\mathrm{KBr})(1 \%$ of the sample and $99 \%$ of $\mathrm{KBr}$ ). Accusizer 770 (particle marker of PSS Santa Barbara) was used to determine the particle size distribution. For the measurement of apparent porosity, water absorption and density, the procedure described in ASTM C37388 method was used while firing shrinkage was conducted according to ASTM-C326 (2003). The mechanical strength was measured according to ASTM C674-88. The shaped specimens used for mechanical strength were rectangular $(60 \mathrm{~mm} \times 22 \mathrm{~mm})$ with the repetition of each formulation 3 times and the results were calculated on average. The thermal conductivity of elaborated ceramics was carried on TC3000 hot wire thermal conductivity tester (XIATECH, China). The chemical resistance of the specimens was analyzed by weight loss after contact with $\mathrm{HNO}_{3}, \mathrm{HCl}, \mathrm{H}_{2} \mathrm{SO}_{4}$ solutions $(\mathrm{pH}=1)$ and $\mathrm{NaOH}$ solution $(\mathrm{pH}=12)$. Morphological observations were carried out by scanning electron microscopy (SEM) using a Hitachi-3400N. Chemical microanalyses were developed using energy dispersive spectroscopy (EDS) with an Oxford (Penta FET-125 Precision).

\section{Mix Proportions and Preparation Process of the Composites}

Raw materials were washed with acids to remove heavy metals, grounded, dried and mixed in the proportions given in Table-1. The mixtures were spread out in a stainless steel mold while they were pressed under 11 tons using a hydraulic press for 5 minutes to obtain compacted discs which were then sintered in a programmable furnace (type Controller P 320 Nabertherm).

A thermal program with three stages was established: 250,750 and $1100^{\circ} \mathrm{C}$. The heating rate and time length of temperature plates are respectively $3^{\circ} \mathrm{C} / \mathrm{min}$ and $2 \mathrm{~h}$ for each plate. Figure- 1 shows the used thermal program and Fig.-2 presents the samples aspect before and after heat treatment.

Table-1 : Mix-Design prepared for the Production of Samples.

\begin{tabular}{c|c}
\hline Clay $(\%)$ & Phosphogypsum Content $(\%)$ \\
\hline 100 & 0 \\
\hline 90 & 10 \\
\hline 85 & 15 \\
\hline 80 & 20 \\
\hline 75 & 25 \\
\hline 70 & 30 \\
\hline 65 & 35 \\
\hline 60 & 40 \\
\hline 55 & 45 \\
\hline 50 & 50 \\
\hline
\end{tabular}




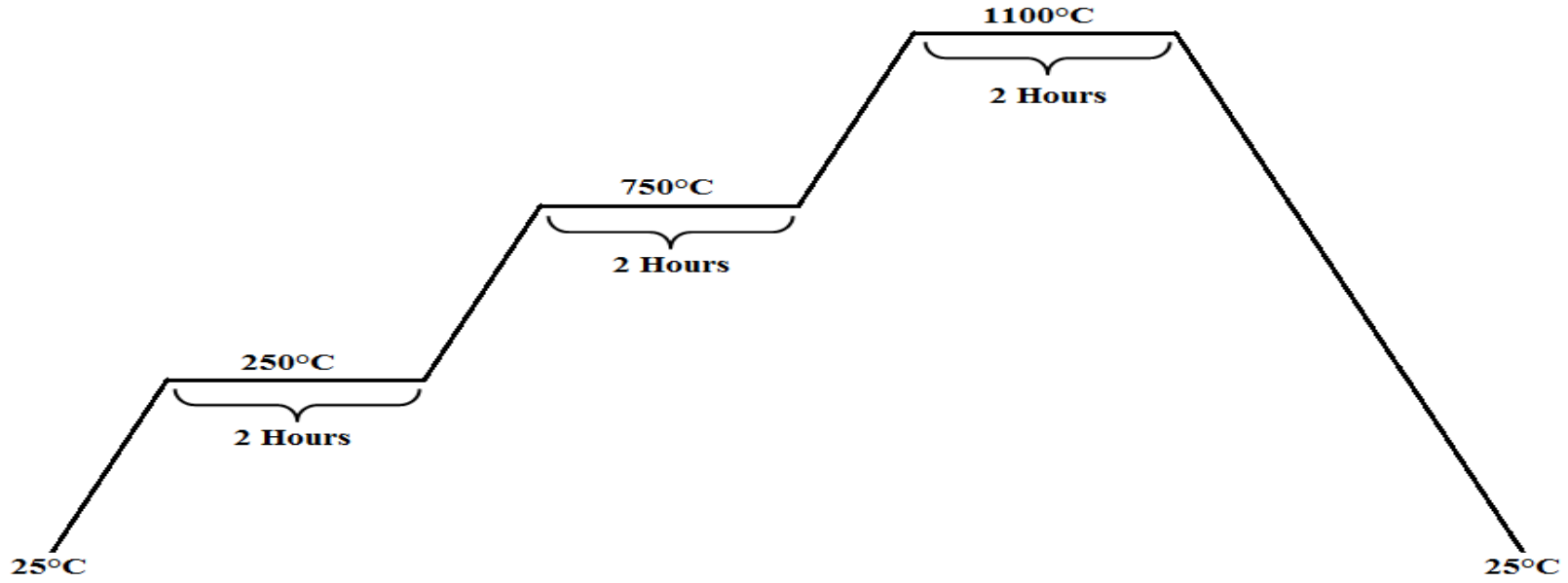

Fig.-1 : The Thermal Program used in the Current Study.

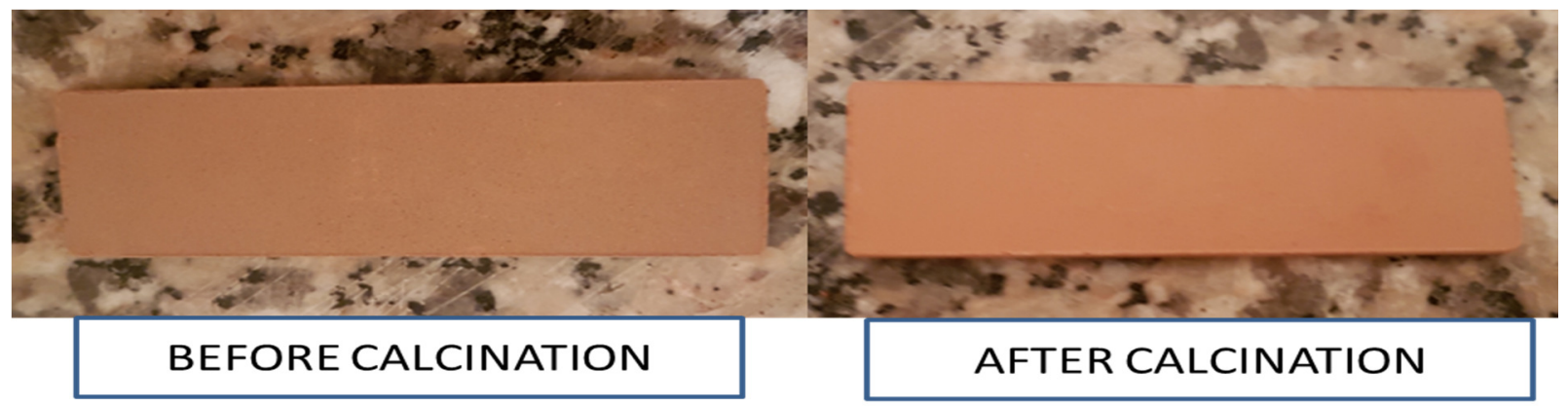

Fig.-2: The specimens prepared before and after the heat treatment $\left(40 \% \mathrm{Wt} \mathrm{PG}, 1100^{\circ} \mathrm{C}\right)$

\section{Characterization of the Raw Materials \\ Granularity}

RESULTS AND DISCUSSION

Figure-3 presents the granulometric curves of the studied PG and Clay. The Fig.-3.A shows that the particle size of the phosphogypsum powder varies from 1 to $100 \mu \mathrm{m}$ and the average particle size (d 50) is $55 \mu \mathrm{m}$. The Fig.-3.B shows that the average particle size of the clay is about $50 \mu \mathrm{m}$.
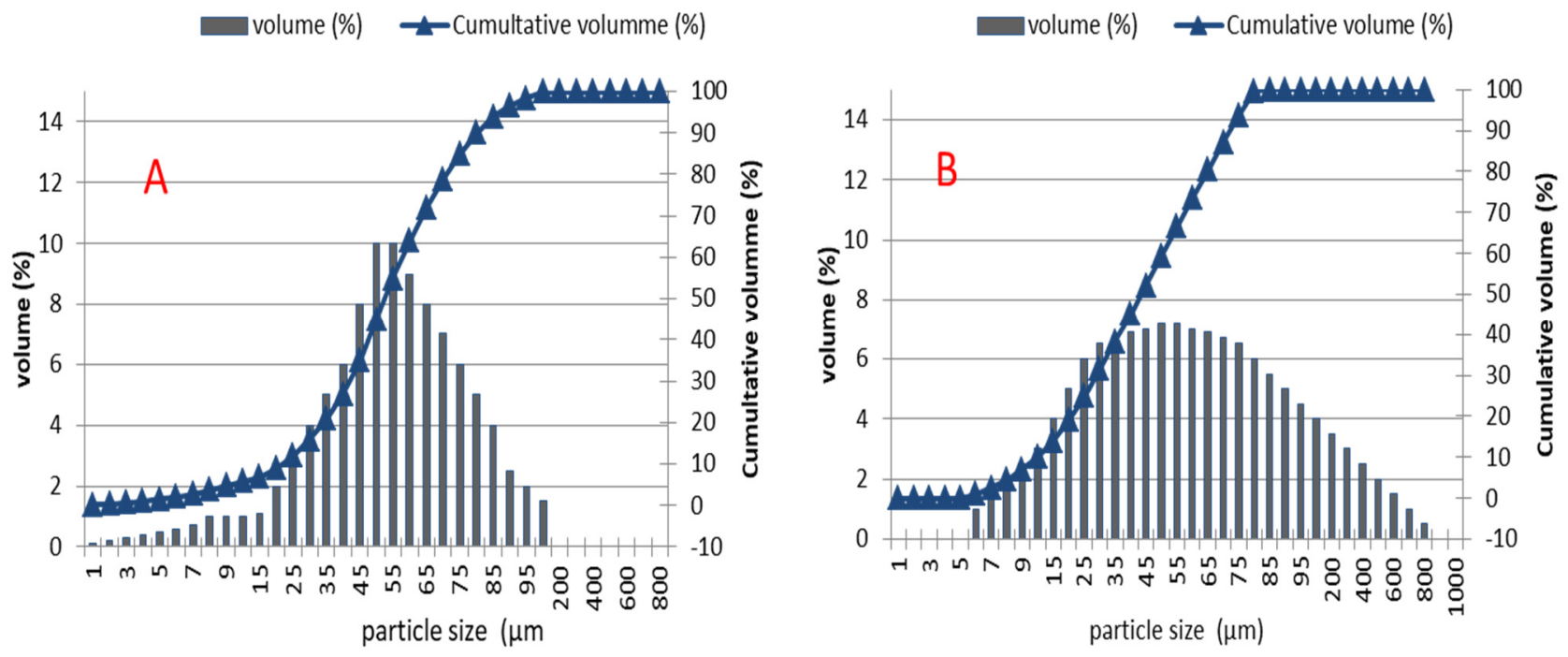

Fig.-3 : Particle Size Distribute of PG (A) and Red Clay (B). 
RASĀYAN $J$. Chem.

Vol. 11 | No. 4 |1552 - 1563| October - December | 2018

\section{Chemical Composition}

The chemical compositions of the clay and PG are presented in Table-2. The phosphogypsum is mainly composed of calcium sulfate (78\%) and calcium phosphate in various forms. Silica and other impurities such as iron, magnesium and aluminum oxides, organic matter and traces of metals are as well detected. The quantity of silica is very low $\left(0.23 \mathrm{wt} \%\right.$ of $\left.\mathrm{SiO}_{2}\right)$, which would need a lower the temperature of the heating during ceramics manufacturing. It emerges from this table that the clay is a silico-alumina clay characterized by a high content of $\mathrm{Al}_{2} \mathrm{O}_{3}$ and $\mathrm{SiO}_{2}$ with moderate contents of iron oxide. This clay also contains non-negligible proportions of $\mathrm{CaO}$ and $\mathrm{MgO}$ which indicate the presence of calcite. The chemical composition of prepared mixtures is presented in Table-2. This analysis shows that the percentage of silica, alumina and iron oxide decreased as the PG increased. Additionally, these constituents form the main skeleton of the product makes it acceptable for the use in ceramics.

Table-2 : Chemical Composition of Clay and Phosphogypsum.

\begin{tabular}{|c|c|c|c|c|c|c|c|c|c|c|c|c|}
\hline & $\mathrm{CuO}$ & $\mathrm{ZnO}$ & $\mathrm{CaO}$ & $\mathrm{K}_{2} \mathrm{O}$ & $\mathrm{MgO}$ & $\mathrm{Na}_{2} \mathrm{O}$ & $\mathrm{P}_{2} \mathrm{O}_{5}$ & $\mathrm{SO}_{3}$ & $\mathrm{Al}_{2} \mathrm{O}_{3}$ & $\mathrm{Fe}_{2} \mathrm{O}_{3}$ & $\mathrm{MnO}_{2}$ & $\mathrm{SiO}_{2}$ \\
\hline & $\%$ & $\%$ & $\%$ & $\%$ & $\%$ & $\%$ & $\%$ & $\%$ & $\%$ & $\%$ & $\%$ & $\%$ \\
\hline Clay & 0,01 & 0,02 & 2,10 & 0,18 & 1,57 & 0,80 & 0,12 & 0,75 & 11,44 & 4,29 & 0,09 & 59,32 \\
\hline Phosphogypsum & 0,001 & 0,001 & 33.11 & 0,08 & 0.008 & 0,13 & 1,64 & 45.13 & 0.06 & 0.06 & 0,001 & 0.23 \\
\hline $\begin{array}{c}\text { Clay }+ \\
\text { Phosphogypsum } \\
\text { (40\% Wt PG) }\end{array}$ & 0.001 & 0.001 & 14.97 & 0.16 & 0.86 & 0.57 & 0.64 & 6.88 & 8.47 & 3.19 & 0.04 & 54.27 \\
\hline
\end{tabular}

\section{FTIR Analysis}

The FTIR spectra analysis is shown in Fig.-4A, 4B and 4C. Various vibration bands associated with the phosphogypsum were detected (Fig.-4A): bands at 650 and $585 \mathrm{~cm}^{-1}$ associated with vibration $v 4 \mathrm{SO}_{4}$ are very sharp and very strong. The wavelength vibration at 1132 and $1073 \mathrm{~cm}^{-1}$ associated with $v 1 \mathrm{SO}_{4} \mathrm{were}$ marked. The vibration band of water appeared at $1628 \mathrm{~cm}^{-1}\left(\mathrm{v}_{2} \mathrm{H}_{2} \mathrm{O}\right)$. The band at $2000 \mathrm{~cm}^{-1}$ is also fairly marked, as the bands at 3564 and $3420 \mathrm{~cm}^{-1}$ of $v 1 \mathrm{H}_{2} \mathrm{O}$.

Fig.-4B shows the FTIR analysis of the clay. According to this figure, vibrational bands of valence between 3400 and $3600 \mathrm{~cm}^{-1}$ and deformation relative to the $\mathrm{OH}$ hydroxyl groups are presented. The vibration bands of valence at 3400 and $3500 \mathrm{~cm}^{-1}$ and the deformations at 1619 and $1641 \mathrm{~cm}^{-1}$ are characteristic of the vibration of the hydroxyl function of the water of hydration of the clay ${ }^{20}$. The Si-O group band, intense centered around 1139, 639 and $485 \mathrm{~cm}^{-1}$ are ascribed to binding valence vibration in clay minerals ${ }^{20}$. The vibrational band of valence at $2039 \mathrm{~cm}^{-1}$ is attributed to the characteristics of the $\mathrm{CO}$ stretching, which confirms the presence of carbonates and other organic impurities in the clay.

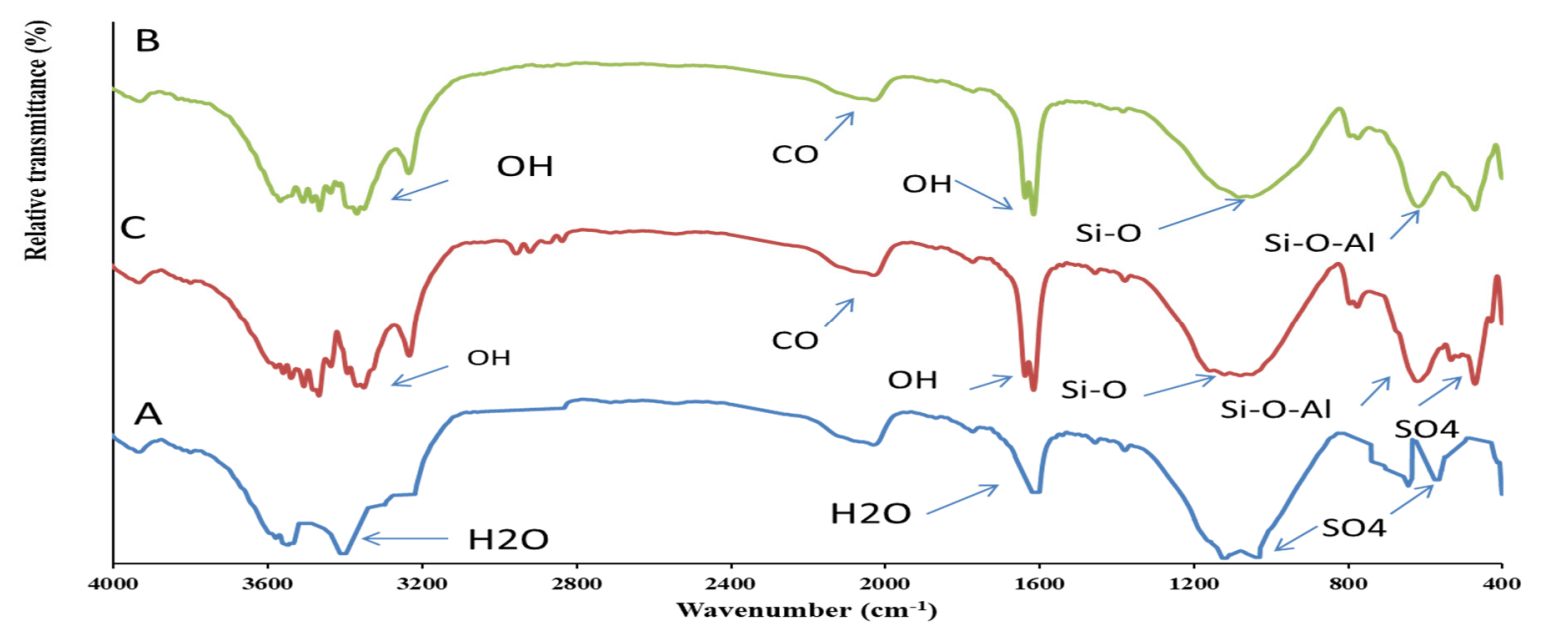

Fig.-4: The FTIR Spectrum of the Materials A: the PG, B: the Red Clay and C: the Elaborated Materials (Clay + Phosphogypsum (40\% Wt PG). 
RASĀYAN J. Chem.

Vol. 11 | No. 4 |1552 - 1563| October - December | 2018

The FTIR spectrum of the elaborated materials shown in Fig. $4 \mathrm{C}$ showed the same tendency as that of the clay with an increase in the intensity of the band corresponding to the CO stretching $\left(2039 \mathrm{~cm}^{-1}\right)$.

\section{XRD Characterizations}

XRD patterns of the phosphogypsum, clay and the prepared samples are showed in Fig.-5. Figure-5 shows the mineral composition of PG which was dominated by gypsum(78.24\%) and then quartz $(0.23 \%)$. In another hand, the red clay showed that it is formed mainly of quartz and calcite and traces of hematite and dolomite. The XRD results correlate with those of the infrared spectroscopy and are also coherent with the previous studies ${ }^{20}$.
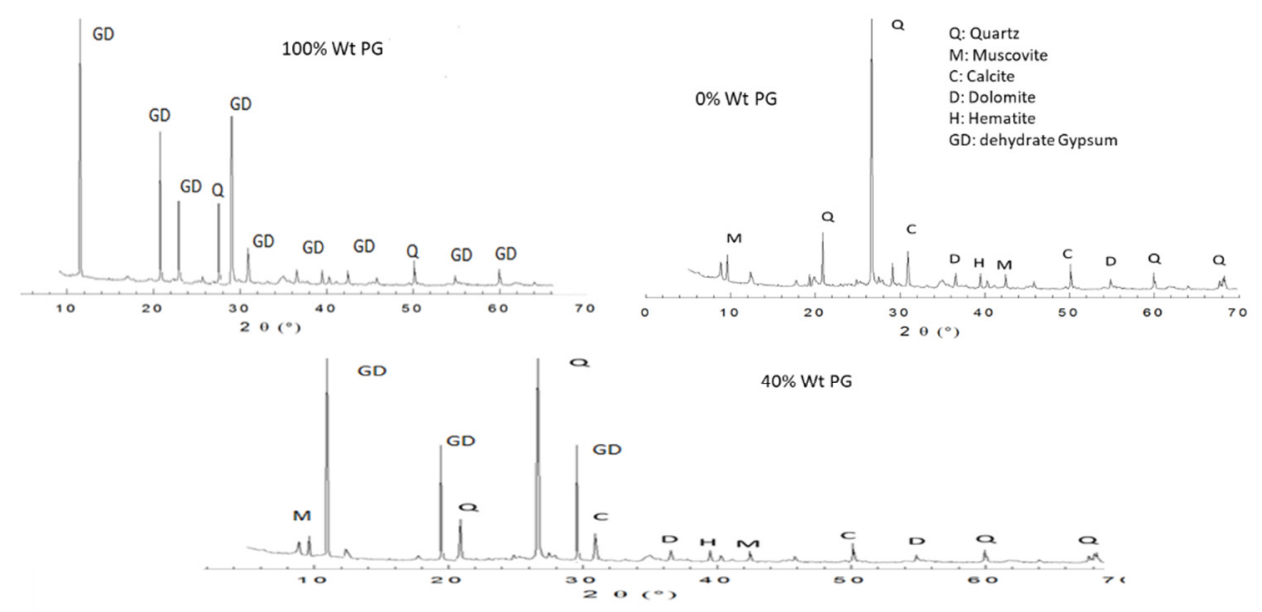

Fig.-5: The XRD Patterns of Prepared Material.

\section{Characterization of the Prepared Samples \\ Firing Shrinkage}

The firing shrinkage primarily depends on: mineralogical composition of the clay, its texture, shaping conditions and the amount of the material. The shrinkage is calculated by the following equation:

$$
R=\frac{\mathrm{Lf}-\mathrm{Lc}}{L f}
$$

Where $\mathrm{L}_{\mathrm{f}}$ and $\mathrm{L}_{\mathrm{c}}$ are the sample length before and after firing, respectively. The shrinkage phenomenon is closely related to the calcination phenomenon that occurs during samples firing. At some point of the heat cycle, the microstructure is taking place, for transporting material between the grains, in order to minimize the excess of interface energy, which is generally accompanied by a decrease in porosity. The dimensional variation is related to the elimination of the components (with eventual creation of an internal gas pressure) and to the structural reactions and transformations. Fig. 6 shows that the firing shrinkage increases with PG addition. It is noticed that only from the composition containing $40 \%$ of PG the values of shrinkage become higher than $8 \%$ which is the maximum limit allowed by the standards. ${ }^{21}$

Another study of the incorporation of PG in the building bricks and fired products in order to enhance this PG gave a shrinkage exceeding $7.2 \% .22,23$

\section{Density}

The density of clay materials is an important parameter. Generally, the absolute (non-porous) clay density is less than $2.8 \mathrm{~g} / \mathrm{cm}^{3}$. It is related to the chemical composition of the raw materials (higher density with high concentrations of aluminum and iron) and the product structure (higher density if it is crystalline). The addition of PG increases the density until $2.41 \mathrm{~g} / \mathrm{cm}^{3}(50 \% \mathrm{PG})$ as shown in Fig.-7. Other studies 
RASĀYAN J. Chem.

Vol. 11 | No. 4 |1552 - 1563| October - December | 2018

concern the preparation of non-autoclaved aerated concrete with the phosphogypsum gives as best result $0.7 \mathrm{~g} / \mathrm{cm}^{324}$.

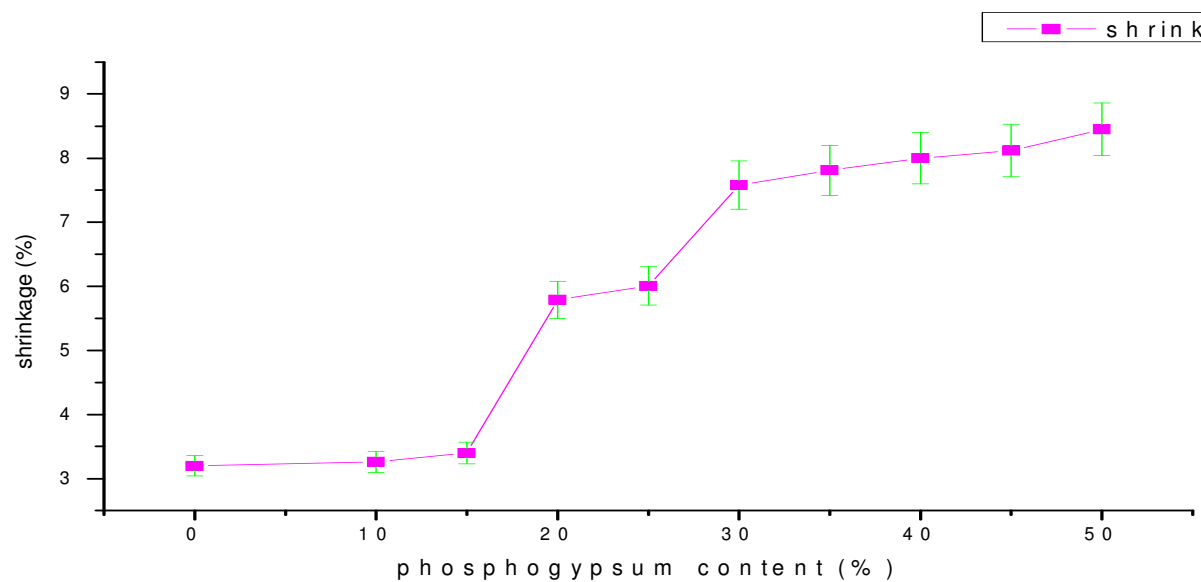

Fig.-6: Change of Firing Shrinkage Versus Phosphogypsum Content.

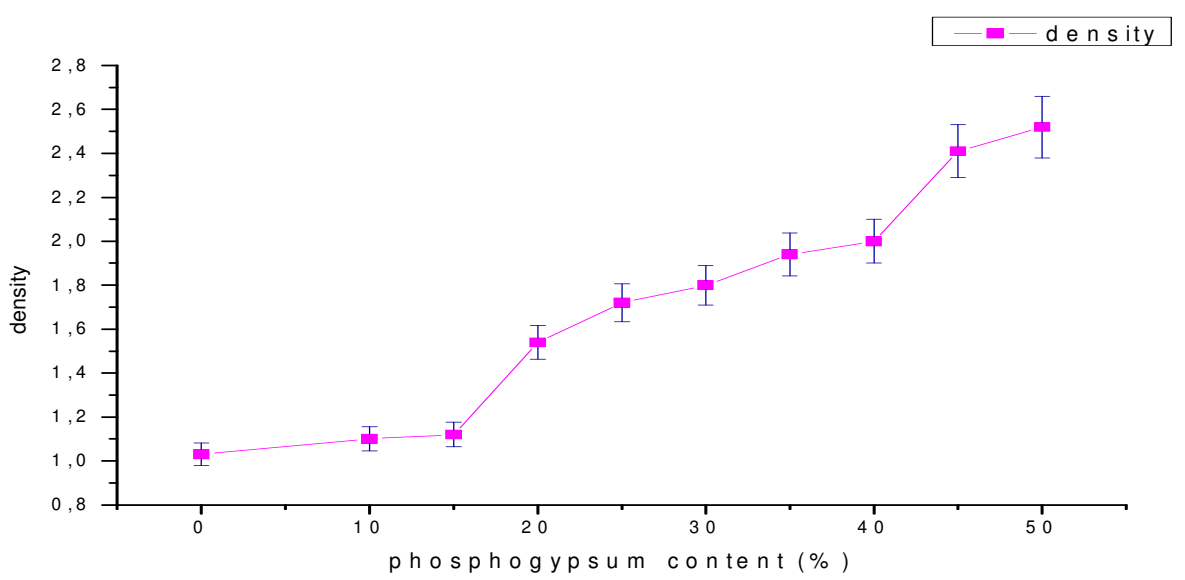

Fig.-7: Variation of Density against Phosphogypsum Content.

\section{Porosity}

The porosity is the most important parameter for all the composite properties because it influences the mechanical strength and, water absorption of the composites. The porosity can be opened or closed. Depending on the product, different porosities are sought, low porosity $(<20 \%)$ for the tiles and exposed ceramics and high porosity $(>40 \%)$ for certain types of low thermal conductivity ceramics. ${ }^{22}$

The addition of PG increases the porosity of the samples up to the highest value (43\%) which remains below the standard limit (50\%) (Fig.-8). This is owing to the weakening of the plastic properties of the mixing and by the decreasing of the cohesion and increasing of the pore size inside the ceramic.In addition, the important presence of calcite $\left(\mathrm{CaCO}_{3}\right)$ in phosphogypsum influences the evolution of the porosity of the final product by the transformation of $\mathrm{CaO}$ to portlandite $\left[\mathrm{Ca}(\mathrm{OH})_{2}\right]$ and release of $\mathrm{CO}_{2}$.

\section{Water Absorption}

The water absorption is a principal factor for the durability of the product and its behavior to the natural environment. Figure-9 presents the variation of the water absorption with an added amount of PG.For the studied case, the absorption coefficient increased by the increase of the percentage of the PG but it remained below the standard limit $(25 \%)^{21}$, this increase can be explained by the departure of carbon dioxide. Other studies ${ }^{22}$ has yielded in high values of water absorption (13.4\%) for the valorization of PG in clay bricks. 
RASĀYAN J. Chem.

Vol. 11 | No. 4 |1552 - 1563| October - December | 2018

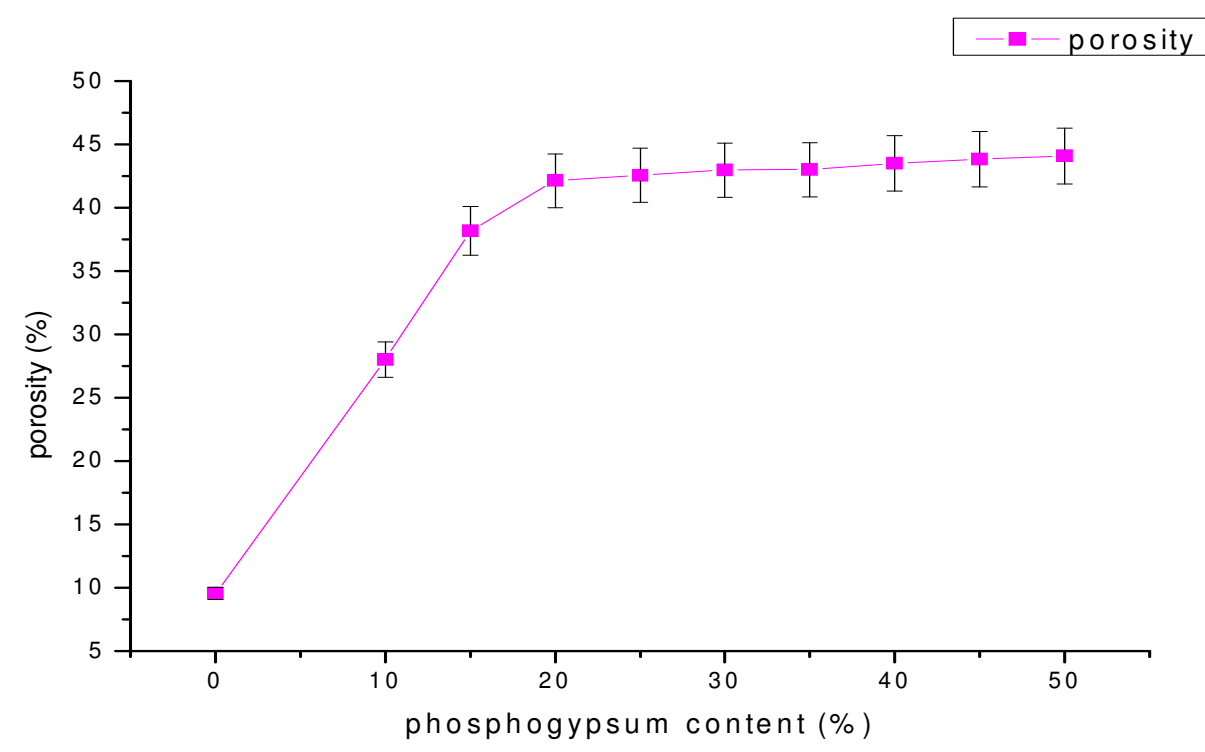

Fig.-8: Change of Apparent Porosity Versus Phosphogypsum Content.

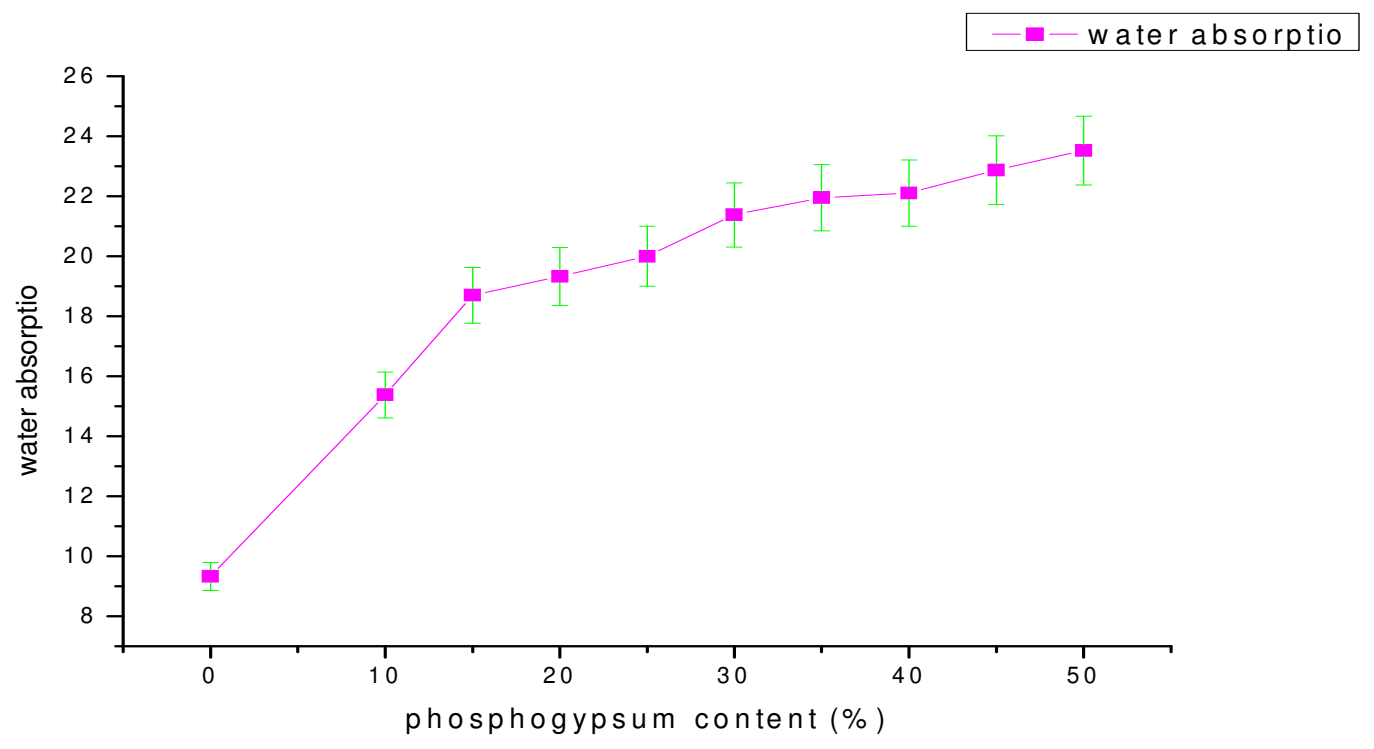

Fig.-9: Variation of Water Absorption against Phosphogypsum Content.

\section{Compressive Strength}

The compressive strength is the most important mechanical property of composite materials. It gives a clear idea about the quality of the studied product.

The results, obtained as an average of measurements performed on the specimens, are shown in Fig.-10. It may be noted that the mechanical properties are influenced by the amount of PG incorporated into the samples. Increasing the proportion of PG resulted in the decrease in mechanical performances. Thus, the samples become more porous causing a decrease in the mechanical strength. For all studied cases, the strength of the samples is higher than $2.3 \mathrm{MPa}$, which is the minimum strength indicated by the standards ${ }^{21}$. Compared with the current study, previous studies exhibited low mechanical performances. ${ }^{15,22,24-29}$

\section{Chemical Resistance}

Resistance tests of chemical corrosion were performed on the specimens. The samples were penetrated at $25^{\circ} \mathrm{C}$ in a bath of hydrochloric acid $(\mathrm{pH}=1)$, sulfuric acid $(\mathrm{pH}=1)$, nitric acid $(\mathrm{pH}=1)$ and sodium hydroxide $(\mathrm{pH}=12)$. The weight is checked every 24 hours for 7 days. 


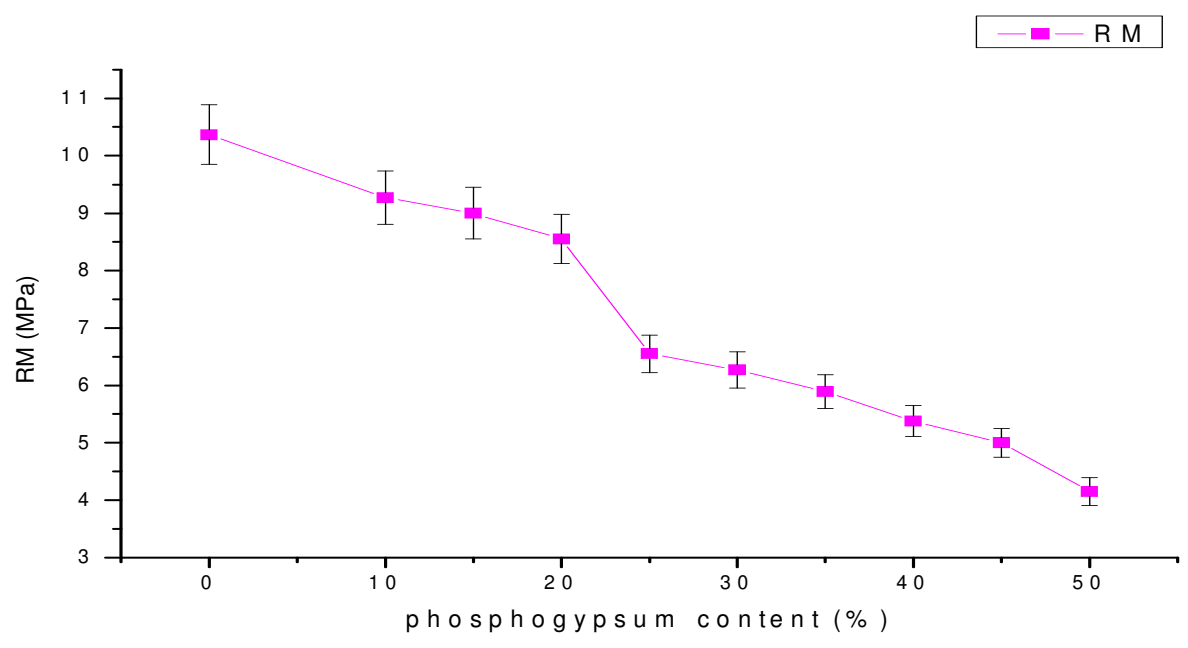

Fig.-10: Change of Mechanical Properties Versus Phosphogypsum Content.

The samples were then washed with water and dried. The evolution of weight loss with the attack in acidic and basic solutions represented respectively in Fig.-11. For our samples, it was observed that the most corrosive solution is sulfuric acid and chemical resistance of the samples increases with the addition of PG (Fig.-12).

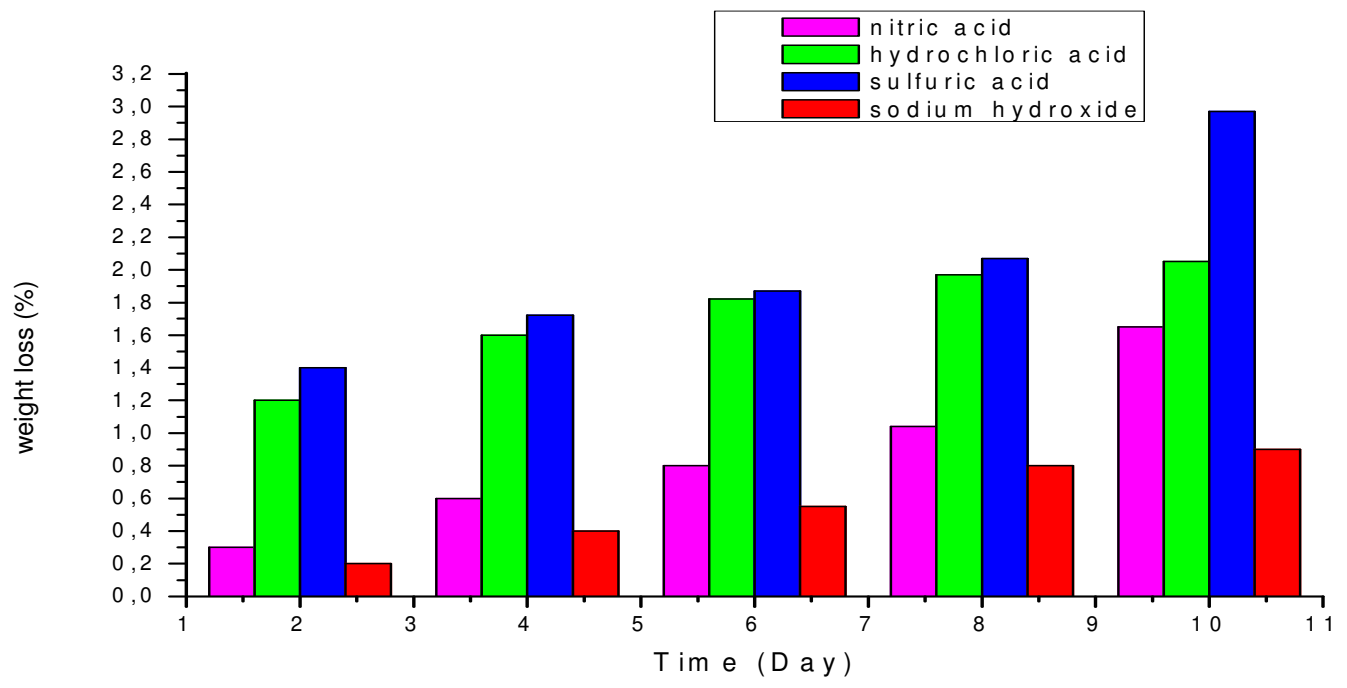

Fig.-11: Weight Loss of the Prepared Materials in Both Basic and Acid Mediums.

\section{The Thermal Conductivity of Elaborated Ceramics}

Thermal conductivity is a physical parameter characterizing the behavior of materials during thermal transfer by conduction. It represents the energy (amount of heat) transferred per unit area and time under a temperature gradient of 1 Kelvin. Results of thermal conductivity of elaborated ceramics are displayed in Fig.-13. For the studied case, the thermal conductivity decreased by the increase in the percentage of the PG until $0.09 \mathrm{~W} \cdot \mathrm{m}^{-1} \cdot \mathrm{K}^{-1}$.In addition, it is found that the addition of PG increases porosity, which translates, by a decrease in thermal conductivity. From these results, we can finally conclude that porosity-induced during the implementation of the material reduces the thermal conductivity.

\section{The Structure Study}

The best properties were demonstrated by the ceramics start with compositions containing a $40 \% \mathrm{Wt}$ of phosphogypse content. Therefore, samples were chosen for the study of physical processes involved in 
RASĀYAN J. Chem.

Vol. 11 | No. 4 |1552 - 1563| October - December | 2018

the physico-chemical interaction between the components of these mixtures during sintering and to study the structure of the obtained ceramic materials.

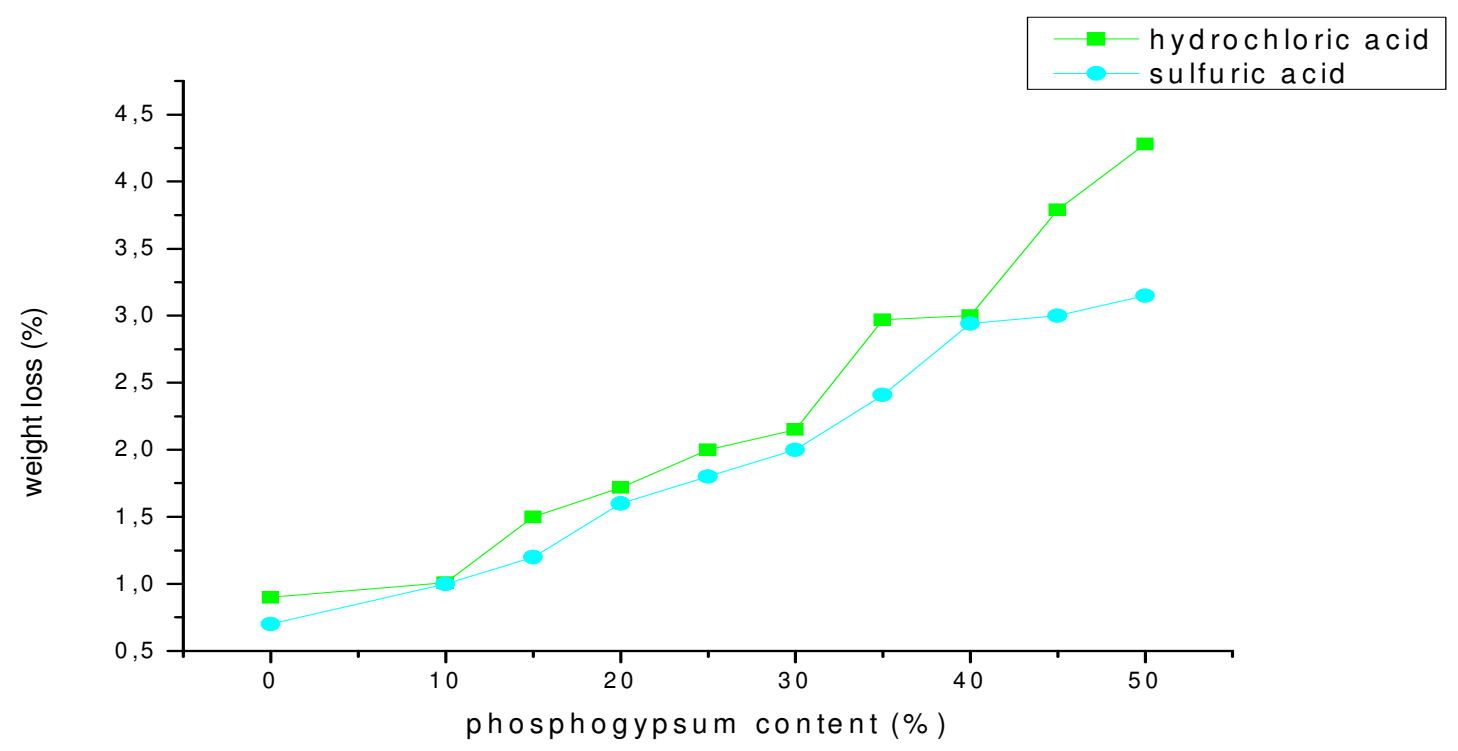

Fig.-12: Weight Loss of the Prepared Materials against Phosphogypsum Content.

The morphology and distribution of the different phases and of porosity in sintered samples were analyzed by microstructural observation. SEM micrographs (Fig.-14) for clay samples (A and B) and for clay with $25 \mathrm{wt} \%$ phosphogypse $(\mathrm{C}$ and $\mathrm{D})$, sintered for $8 \mathrm{~h}$ at $1100^{\circ} \mathrm{C}$, showed that microstructure $\mathrm{A}$ and $\mathrm{B}$ got a higher amount of interconnected pores than microstructure $\mathrm{C}$ and $\mathrm{D}$, where the pores appear to be more elongated. The ceramic material with $40 \% \mathrm{Wt}$ of phosphogypse is denser than the clay, which is in agreement with the density and water absorption behaviors shown by these samples.

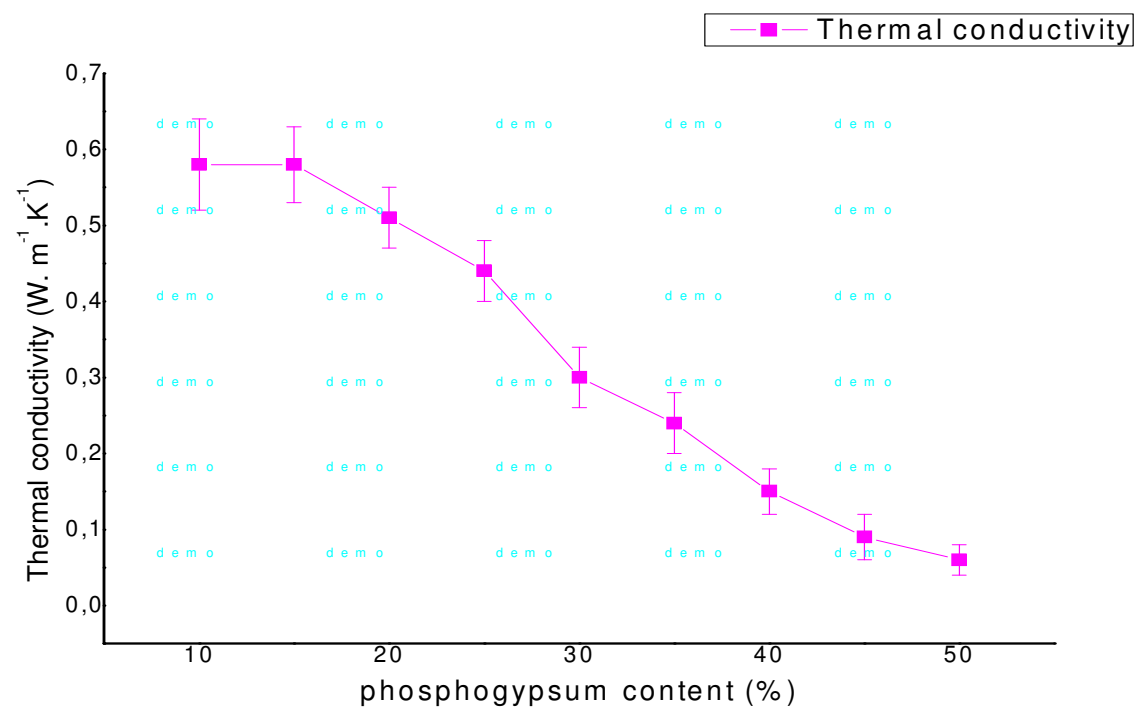

Fig.-13: Thermal Conductivity against phosphogypsum Content.

The weaker densification observed in samples containing a less amount of phosphogypsum is due to a smaller content of oxides that would act as fluxing agents (e.g. $\mathrm{CaO}, \mathrm{Na}_{2} \mathrm{O}$ and $\mathrm{K}_{2} \mathrm{O}$ ) comparatively to clay (Table-2), and also to the presence of carbonate. This will react during the firing process contributing 
RASĀYAN J. Chem.

Vol. 11 | No. 4 |1552 - 1563| October - December | 2018

to increasing the porosity of the final material. Achievement of high density is important because the mechanical properties of the obtained products will improve with the increase in the final density.
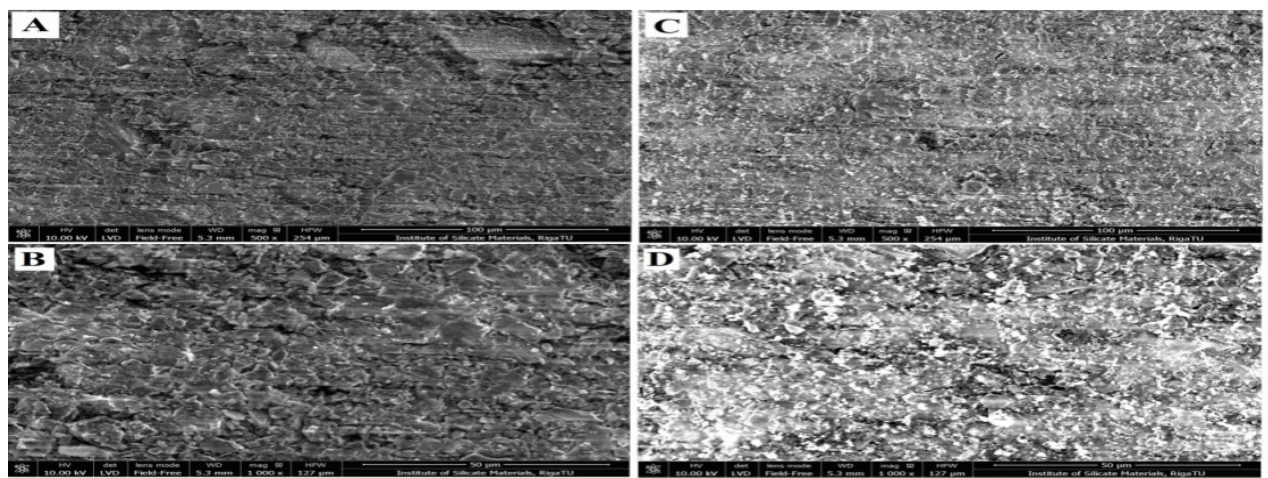

Fig.-14: Scanning Electron Micrographs of Fractured surfaces of Clay (A and B) and of Clay $+40 \% \mathrm{Wt}$ phosphogypsum(C and D), sintered at $1100^{\circ} \mathrm{C}$

The EDS analysis (Table-3) of the chemical composition of the raw materials was consistent with the XRF (Table-2) and XRD (Fig.-4) analysis results. The main inorganic component of phosphogupsum is calcium in amorphous or partially crystalline form, as well as calcite.

The Fig. -15 presents the spots tests. The results of the elemental analysis are displayed in Table- 3 . The ceramic material presented high silicon and magnesium content due to the presence of quartz and cristobalite and rather average amounts of sodium $(\mathrm{Na})$ typical in most ceramics high $\mathrm{Si}$ and $\mathrm{Al}$ contents, which were in illite, as well as iron and minor amounts of other elements. Comparison of the results of chemical analysis of the composite materials by two methods XRF (Table-2) and EDS (Table-3) reveals their significant difference, especially in the number of $\mathrm{Si}, \mathrm{Al}$ and partly of $\mathrm{Ca}$. This difference is determined by the following reason: XRF provides information about the composition of the whole volume of the sample, and EDS only in its composition at three points; at the same time phosphogypsum is extremely difficult material for its characterization by EDS method because of its high content of well visible particles of various diameters and lengths, XRF provides results in the form of oxides and EDS as only the chemical elements.

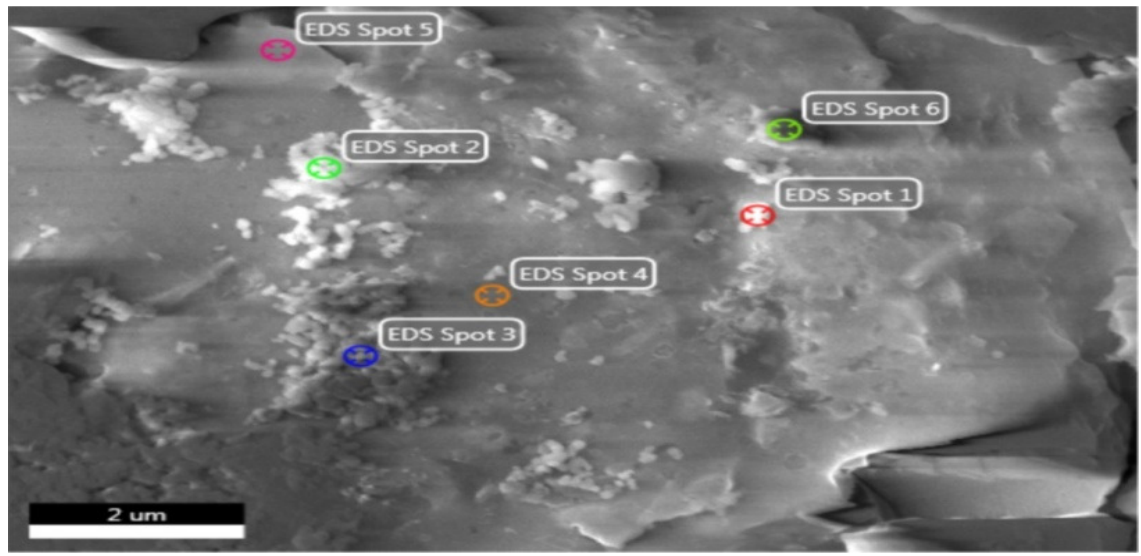

Fig.-15: SEM Micrographs for EDS Analysis of Sample (40\%Wt phosphogypsum) sintered at $1100{ }^{\circ} \mathrm{C}$

Table-3: Chemical compositions of the spots of the ceramic material $40 \% \mathrm{Wt}$ phosphogypsum(by EDS method)

\begin{tabular}{c|c|c|c|c|c|c|c|c|c|c}
\hline & \multicolumn{10}{c}{ Elements \% Wt } \\
\hline & $\mathrm{O}$ & $\mathrm{Na}$ & $\mathrm{Mg}$ & $\mathrm{Al}$ & $\mathrm{Si}$ & $\mathrm{P}$ & $\mathrm{K}$ & $\mathrm{Ca}$ & $\mathrm{Fe}$ & $\mathrm{C}$ \\
\hline Spot 1 & 48.02 & 1.03 & 1.81 & 4.27 & 20.97 & 0.5 & 0.44 & 10.89 & 2.08 & \\
\hline Spot 2 & 43.46 & 0.69 & 1.06 & 5.52 & 21.26 & 0.1 & 1.5 & 11.99 & 3.5 & 10.93 \\
\hline
\end{tabular}


RASĀYAN J. Chem.

Vol. 11 | No. 4 |1552 - 1563| October - December | 2018

\begin{tabular}{c|c|c|c|c|c|c|c|c|c|c}
\hline Spot 3 & 42.84 & 0.74 & 1.09 & 5.55 & 22.12 & 0.23 & 0.94 & 09.74 & 3.09 & 8.67 \\
\hline Spot 4 & 38.05 & 0.71 & 0.58 & 6.87 & 20.95 & 0.33 & 1.97 & 10.28 & 7.88 & 8.36 \\
\hline Spot 5 & 31.45 & 0.19 & 0.26 & 8.98 & 19.19 & 0.4 & 1.51 & 08.49 & 7.96 & 11.57 \\
\hline Spot 6 & 50.18 & 1.74 & 0.58 & 5.03 & 19.94 & 0.51 & 0.58 & 09.81 & 3.41 & 9.22 \\
\hline
\end{tabular}

\section{The Heavy Metals Content of the Materials}

The concentrations of selected the metal species, $\mathrm{Cd}, \mathrm{Pb}$, As, $\mathrm{Ni}$ and $\mathrm{Cr}$, for elaborated materials (Table4 ), were well below regulatory limits. Thus, this result indicates that specimens of composites manufactured can be considered as non-hazardous materials.

Table-4: The concentrations of heavy metals in the elaborate samples.

\begin{tabular}{c|c|c|c|c|c}
\hline & $\mathrm{Cd}$ & $\mathrm{Pb}$ & $\mathrm{As}$ & $\mathrm{Ni}$ & $\mathrm{Cr}$ \\
\cline { 2 - 6 } & $\mathrm{mg} / \mathrm{kg}$ & $\mathrm{mg} / \mathrm{kg}$ & $\mathrm{mg} / \mathrm{kg}$ & $\mathrm{mg} / \mathrm{kg}$ & $\mathrm{mg} / \mathrm{kg}$ \\
\hline Clay & 0.26 & 28.84 & 37.08 & 79.85 & 102.58 \\
\hline Phosphogypsum & 1.02 & 9.52 & 10.84 & 91.22 & 52.89 \\
\hline Clay + Phosphogypsum (40\% Wt PG) $^{3}$ & 0.45 & 21.73 & 25.84 & 85.27 & 74.91 \\
\hline Norme AFNOR $^{\mathbf{3 0}}$ & 2.00 & 100.00 & 100.00 & 100.00 & 150.00 \\
\hline
\end{tabular}

\section{CONCLUSION}

The aim of this study is to incorporate the PG into the manufacture of ceramics. The samples underwent a series of standards tests involving physical, chemical, mechanical and environmental properties. It has been found that up to $40 \%$ of PG, the samples successfully satisfy the standard requirements for the shrinkage. Water absorption and porosity increases as the amount of PG increases. The chemical attacks on the ceramic materials give more weight losses as the amount of PG increases. The mechanical strength of composites decreases depending on increment in PG content in the samples body. The high content of calcium in the PG is the origin of this alteration, but it is higher than $2.3 \mathrm{MPa}$, which is the minimum strength indicated by the standards. The addition of PG reduces the thermal conductivity of the elaborated ceramic thanks to the porosity generated within the material. According to this study, it can be concluded that the elaborated material is a good thermal insulator and resistant against acids with mechanical and physical properties allows integrating the PG in the composition of ceramics.

\section{REFERENCE}

1. R. Pérez-López, A.M. Álvarez-Valero, J.M. Nieto, J. Hazard. Mater.,148, 745 (2007), DOI: 10.1016/j.jhazmat.2007.06.068

2. S. Banu and M.N. Haq, Int. J. Emerg. Trends Eng. Dev., 4, 264 (2015).

3. N. Değirmenci, Constr. Build. Mater., 22, 1857 (2008), DOI:10.1016/j.conbuildmat.2007.04.024

4. H. Tayibi, M. Choura, F.A. Lopez, F.J. Alguacilet, A.L. Delgado, J Env Man., 90(8), 2377 (2009), DOI: 10.1016/j.jenvman.2009.03.007

5. S.K. Sahu, P.Y. Ajmal, R.C. Bhangare, M. Tiwari and G.G. Pandit, J. Radiat. Res. Appl. Sci., 7, 123 (2014), DOI:10.1016/j.jrras.2014.01.001

6. J. Yang, W. Liu, L. Zhang and B. Xiao, Constr. Build. Mater., 23, 687 (2009), DOI:10.1016/j.conbuildmat.2008.02.011

7. I. Akın Altun and Y. Sert, Cem. Concr. Res., 34, 677 (2004), DOI:10.1016/j.cemconres.2003.10.017

8. T. Kuryatnyk, C. Angulski da Luz, J. Ambroise and J. Pera, J. Hazard. Mater., 160, 681 (2008), DOI:10.1016/j.jhazmat.2008.03.014

9. Szynkowska, M. Iwona, A. Pawlaczyk and J. Rogowski, Environ. Sci., (2011), DOI:10.5772/16478

10. M.S. Al-Masri, Y. Amin, S. Ibrahim and F. Al-Bich, Appl. Geochem., 19, 747 (2004), DOI:10.1016/j.apgeochem.2003.09.014

11. J.M. Arocena, P. M. Rutherford and M. J. Dudas, Sci. Total Environ., 162, 149 (1995).

12. P.M. Rutherford, M.J. Dudas and J.M. Arocena, Waste Manag. Res., 13, 407 (1995). 
RASĀYAN J. Chem.

Vol. 11 | No. 4 |1552 - 1563| October - December | 2018

13. J.P. Xia, C.Q. Yang, Y. Su, Yunnan Chem Technol., 1, 21 (2005).

14. N. Degirmenci, A. Okucuand and A.Turabi, Build. Environ., 42, 3393 (2007), DOI:10.1016/j.buildenv.2006.08.010

15. T. Tian, Y. Yan, Z.H. Hu and J. Wuhan, Univ Technol., 07, 22 (2014)

16. J. Zhou, L. Yang and Q. Lin, Appl. Mech. Mater., 275, 2131 (2013), DOI:10.4028/www.scientific.net/AMM.275-277.2131

17. W. Shen, M. Zhou and Q. Zhao, Constr. Build. Mater., 21, 1480 (2007), DOI:10.1016/j.conbuildmat.2006.07.010

18. S. Kumar, Build. Environ., 38, 291-295 (2003).

19. J. Zhou, D. Yu, Z. Shu, T. Li, Y. Chen and Y. Wang, Constr. Build. Mater., 73, 222 (2014), DOI:10.1016/j.conbuildmat.2014.09.075

20. S. Petit, J. Madejova, A. Decarreau, F. Martin, Clay Clay Miner., 47, 103 (1999).

21. Michel KORNMANN. Matériaux de terre cuite- Matières de base et fabrication. (2009).

22. L. Ajam, M. Ben Ouezdou, H.S. Felfoul and R.E. Mensi, Constr. Build. Mater., 23, 3240 (2009), DOI: 10.1016/j.conbuildmat.2009.05.009

23. R. Yongue-Fouateu, F.N. dimukong, A. Njoya, F. Kunyukubundo, and P. K. Mbih, J. Asian Ceram. Soc., 4, 299 (2016), DOI:10.1016/j.jascer.2016.05.008

24. L. Yang, Y. Yan and Z. Hu, Constr. Build. Mater., 44, 600 (2013), DOI:10.1016/j.conbuildmat.2013.03.070

25. M. Loutou, M. Hajjaji, M. Mansori, C. Favotto and R. Hakkou, J. Asian Ceram. Soc., 4, 11 (2016), DOI:10.1016/j.jascer.2015.10.003

26. M.S. Sultana, A.N. Ahmed, M.N. Zaman, M.A. Rahman, P.K. Biswas and P.K. Nandy, J. Asian Ceram. Soc., 3, 22 (2015), DOI:10.1016/j.jascer.2014.10.005

27. K. Divya Krishnan, P.T. Ravichandran and V.K. Gandhimathi, Rasayan journal of chemistry, 10(2), 600(2017), DOI: 10.7324/RJC.2017.1021677

28. S. Prakash Chandar, K. Gunasekaran, N. SaiSandeep, S. Manikandaprabhu, Rasayan Journal of Chemistry, 10(2), 528(2017), DOI: 10.7324/RJC.2017.1021636

29. N. GanapathyRamasamy, R.Dhanya, et al., Rasayan Journal of Chemistry, 10(2),577(2017), DOI: 10.7324/RJC.2017.1021671

30. Norme AFNOR N F U 44-041.

[RJC-4025/2018] 